J. Clin. Chem. Clin. Biochem.

Vol. 28, 1990, pp. $465-470$

(C) 1990 Walter de Gruyter \& Co.

Berlin · New York

\title{
On the Biocompatibility of IBM 2997 Continuous Flow Plateletapheresis
}

\author{
By J. Lindena ${ }^{1}$, Hannelore Burkhardt ${ }^{1}$ and H.-M. Aulmann ${ }^{2}$ \\ 1 Abteilung Klinische Biochemie, Medizinische Hochschule Hannover \\ 2 Abteilung Immunhämatologie und Transfusionsmedizin, Medizinische Hochschule Hannover
}

(Received June 7, 1989/January 4, 1990)

\begin{abstract}
Summary: During the procedure of centrifugation cytapheresis donors occasionally experience adverse clincial reactions. We evaluated the possibility of whether activation of granulocytes and their subsequent release reactions, which may have been triggered by this extracorporeal circuit, were responsible for these adverse effects. Six blood samples were obtained during various set intervals during plateletapheresis. Of these, four samples were taken directly from each donor. The remaining two were drawn from the efferent lines, i.e. those which return blood from the cytapheresis machine back to the donor. Reactive oxygen species produced by granulocytes were monitored by chemiluminescence using microamounts of whole blood or isolated granulocytes. Furthermore, secreted granulocyte products such as neutral proteinase elastase, present in plasma in a complex with $\alpha_{1}$-proteinase inhibitor (complexed elastase), and lysosomal $\beta$-glucuronidase were examined. A complete blood cell count, as well as values of haemoglobin, haematocrit, lactate dehydrogenase, protein, albumin and proteinase inhibitors such as $\alpha_{2}$-macroglobulin and $\alpha_{1}$-proteinase inhibitor were also determined. Complexed elastase increased from a preapheresis value of about $140 \mu \mathrm{g} / \mathrm{l}$ to about $180 \mu \mathrm{g} / \mathrm{l}$ at the end of the cytapheresis. All other clinical chemical and cytological values were 8 to 12 percent lower than preapheresis values, which can be attributed to inherent plasma volume expansion. Reduced chemiluminescence was observed upon stimulation of phagocytes in the whole blood assay (about 700 counts $/ \mathrm{min} \times 10^{3} \times 50000$ cells vs. about 600 counts $/ \mathrm{min} \times 10^{3} \times 50000$ cells). This decrease was also seen with stimulated granulocytes (about 5800 counts $/ \mathrm{min} \times 10^{3} \times 50000$ cells vs. about 4500 counts $/ \mathrm{min} \times 10^{3} \times 50000$ cells). Unstimulated granulocytes, on the other hand, showed an increased native chemiluminescence. These data do not, however, indicate a cytapheresis mediated activation of the oxidative metabolism of granulocytes. Concomitant discharge of proteolytic enzymes remains, therefore, of no clinical importance.
\end{abstract}

\section{Introduction}

Adverse clinical effects of donors during centrifugation cytapheresis have been reported in 4 to 25 percent of cases $(1-3)$. They have been classified as mild in severity and have required no therapy. Clinical signs point, for the most part, to citrate toxicity. A possible alternative explanation is based on the assumption that the mechanical cytapheresis procedure itself mediates activation and release reactions of distinct cell types. The most likely cell type responsible for such a mechanism is the neutrophilic granulocyte, which has significant pathogenic potency, being capable of discharging large amounts of toxic oxygen species and lysosomal neutral proteinases upon chemical or mechanical stimulation. Reactive oxygen species and neutral proteinases have been implicated in the pathogenesis of acute tissue injury, particularly in the lung (4). The activation of granulocyte oxidative metabolism and neutral proteinase release have been detected during extracorporeal circuit procedures such as haemodialysis and cardiopulmonary bypass $(5-10)$. The mechanism involved may also underlie similar clinical adverse reactions during centrifugation cytapheresis Conventional laboratory programmes (2) designed to monitor the safety of cytapheresis are not specific for granulocytic activation and/or secretory products. 
Investigations of complement activation (11) and functional analysis of monocytes and lymphocytes during cytapheresis have been reported $(12,13)$. Similar studies with granulocytes, however, remain to be performed. The present investigation thus explores humoral and cellular parameters in donor blood as well as efferent blood taken from the IBM $2997 \mathrm{cy}-$ tapheresis machine. A key feature of this particular unit is a ceramic rotary seal. It has been hypothesized that the levels of shear stress in the rotary seal and/ or contact with the ceramic surface of the seal may cause damage to blood cells (14). The emphasis of the investigation was placed on parameters indicative of the activation of granulocytes and subsequent product release, but general cell injury markers were also included.

Parameters of the investigation included the production of reactive oxygen species, which were monitored by chemiluminescence within microamounts of whole blood or isolated granulocytes. Amounts of granulocyte products, such as neutral proteinase elastase and lysosomal $\beta$-glucuronidase, were determined. Proteinase inhibitors, such as $\alpha_{2}$-macroglobulin and $\alpha_{1}$-proteinase inhibitor, were also evaluated. A differential blood cell count, as well as haemoglobin, haematocrit, lactate dehydrogenase, protein, and albumin determinations, were included.

\section{Materials and Methods}

\section{General design}

Blood was collected from healthy donors fulfilling the usual requirements for blood donation. Informed consent was obtained. Cells were collected by continuous flow centrifugation using a cell separator (Model 2997, International Business Machines, Princeton, NY, USA) with centrifuge speed set at 1500 $\min ^{-1}$.

\section{Plateletapheresis}

Forty eight donors were investigated. Four litres of blood were processed during approximately 1.5 hours. Acid-citrate-dextrose (ACD-A, Pfrimmer, FRG) was used in a 1 to 8 ratio with whole blood for the first litre and thereafter in a 1 to 10 ratio. Heparin (2500 I. U., Liquemin, Hoffmann La-Roche, Switzerland) was given prior to plateletapheresis. Whole blood entered the channel while approximately $250 \mathrm{ml}$ of primer saline containing 1000 I. E./l heparin (Vetren 200, Promonta, Hamburg, F. R. G.) was extracted from the unit. The separation was then started and after 41 of blood had been processed, $250 \mathrm{ml}$ of saline with heparin were again extracted from the unit.

Blood collection times for isolation of granulocytes and plasma separation

Five $\mathrm{ml}$ anticoagulated blood ( 9 vol blood 1 vol sodium citrate, $31.3 \mathrm{~g} / \mathrm{l}$ ), were withdrawn directly from each donor undergoing cytapheresis at the following times: before (Pre), half-way through (Half), at the end of (End), and 30 min after termination of cytapheresis (Post). A blood sample $(5 \mathrm{ml})$ was also drawn from the efferent line of the cytapheresis machine with- out citrate supplementation. Evaluations were made at the half way point (Half) and at the end of the procedure (End). Blood samples $(2 \mathrm{ml})$ were simultaneously collected in EDTA coated tubes for cell counts.

Plasma

An aliquot of citrated blood was centrifuged and the plasma stored at $-70{ }^{\circ} \mathrm{C}$ for clinical chemical analysis.

\section{Isolation of granulocytes}

Granulocytes were separated from the interface of a two-step discontinuous Percoll ${ }^{\circledR}$ gradient (Pharmacia, Sweden) $(15,16)$.

\section{Chemiluminescence of whole blood and isolated granulocytes}

Upon interaction with particulate stimuli or chemical stimulation, phagocytes respond with a chain of biochemical and cytophysiological events commonly known as the respiratory burst. An increased oxygen consumption of the cells is largely converted into excited oxygen species which react with certain biological substrates to become electronically excited products, which generate light upon relaxation. The relatively poor quantum yield of this native chemiluminescence response can be increased more than a thousand fold by using cyclic hydracides, such as luminol, as the bystander substrate (17). The major chemiluminescence response of granulocytes to the particulate stimulatory agent, zymosan, is brought about by the interaction of the complement receptor type 3 of granulocytes with the plasma-derived zymosan-coated cleavage products of complement fraction three, $\mathrm{iC} 3 \mathrm{~b}$ and to a minor degree $\mathrm{C} 3 \mathrm{~b}$. In the absence of plasma this receptor also mediates a chemiluminescence response from the interaction with the zymosan polysaccharide component, glucan (18).

Chemiluminescence assays of whole blood phagocytes and isolated granulocytes were performed in polystyrene chemiluminescence vials at $37^{\circ} \mathrm{C}$ using a Biolumat 9505 equipped with a six channel device (Berthold, Wildbad, F. R. G.). The vials were not stirred during the assay. Chemiluminescence reaction mixtures for isolated granulocytes and whole blood were constituted as follows (18).

\section{Isolated granulocytes}

$500 \mu \mathrm{l}$ Minimal Essential Medium Dulbecco (MEM) with $10 \mu \mathrm{l}$ luminol $(0.4 \mathrm{mmol} / 1$ final concentration) as the chemiluminogenic agent, together with either $20 \mu$ autologous plasma (CL1) or $20 \mu \mathrm{l}$ MEM instead of plasma (CL2). Twenty $\mu$ l granulocyte suspension $\left(0.5 \times 10^{5}\right.$ cells $)$ were added to both vials. After 5 min incubation, the reaction was started with $20 \mu \mathrm{l}$ nonopsonized zymosan $(3.5 \mathrm{~g} / \mathrm{l})$. Controls without stimulus were run in parallel ( $\mathrm{C} 1$ and $\mathrm{C} 2)$.

\section{Whole blood}

$500 \mu \mathrm{l} \mathrm{MEM}$ and $10 \mu \mathrm{l}$ luminol $(0.4 \mathrm{mmol} / \mathrm{l})$ plus $40 \mu \mathrm{l}$ whole blood (CL1). After $5 \mathrm{~min}$ incubation, the reaction was started with $20 \mu \mathrm{l}$ non-opsonized zymosan $(3.5 \mathrm{~g} / \mathrm{l})$. A control without stimulus was also included (C1).

Chemiluminescence was continuously recorded. The following chemiluminescence parameters were calculated from the measurements:

(i) peak maximum counts/min values for the stimulation reactions (CL1 and CL2) as well as for the controls (C1 and $\mathrm{C} 2$ ), representing the oxygenation capacity and the native chemiluminescence, respectively. 
(ii) peak time values measured as the time in minutes required to reach the peak maximum, representing an index of receptor affinity and/or concentration.

Haematological values and plasma chemistry

Studies included a complete blood cell count (erythrocytes, thrombocytes, leukocytes, neutrophils, monocytes, lymphocytes), and the determination of haemoglobin and haematocrit by standard procedures. Plasma analysis included: lactate dehydrogenase using a standard UV test; $\alpha_{1}$-proteinase inhibitor using benzoyl- $D, L$-arginine- $p$-nitroanilide (a chromogenic substrate); $\alpha_{2}$-macroglobulin using carbobenzoxy-valylglycyl-arginine-p-nitroanilide (a chromogenic substrate) (Boehringer, Mannheim, FRG) $(19-21)$; granulocyte elastase as elastase- $\alpha_{1}$ proteinase inhibitor complex (complexed elastase) using a solid phase, enzyme-linked immunoassay (Merck, Darmstadt, FRG) (22); $\beta$-glucuronidase using a fluorimetric substrate (23); protein using a standard biuret procedure; and albumin using the bromocresol green method (24).

\section{Data analysis}

Due both to intravenous infusion and extravascular fluid movement into the intravascular space, samples obtained during cytapheresis were somewhat diluted. Data presented in table 1 are not corrected for the dilution. This holds true for all values, except those of chemiluminescence, which are related to a constant cell number. A correction factor was calculated by dividing the albumin concentration in the preapheresis sample by the albumin concentration in the sample during and following apheresis. Statistical significance was tested against the donor preapheresis value with Student's paired t-test.

\section{Results}

Adverse clinical reactions were not observed during the investigation. Aside from complexed elastase, all cytological and plasma chemical values were lower both during and after cytapheresis, as compared with the corresponding preapheresis values. The observed decreases, however, were slight, but for the most part they were statistically significant (tab. 1). The values remained within their normal ranges. During plateletapheresis the actual values were 8 to 12 percent lower than those obtained before apheresis. These decreases were ascribed to plasma volume expansion by ACD solution. Noteworthy among the cytological values were significant decreases in the lymphocyte and monocyte counts, but not in the granulocyte count; this was caused by cell loss into the collection bags (25) as indicated by exceptionally low values in machine efferent fluid.

Only the complexed elastase concentration increased. Using values adjusted for dilution, an increase over the preapheresis value of about $140 \mu \mathrm{g} / 1$ to about 180 $\mu \mathrm{g} / \mathrm{l}$ was observed in the plasma of probands. Higher values were found in machine efferent fluid than in corresponding donor fluid.

Chemiluminescence peak maximum values decreased in whole blood (about 700 counts/min $\times 10^{3}$ $\times 50000$ cells vs. about 600 counts $/ \mathrm{min} \times 10^{3}$ $\times 50000$ cells) as well as in isolated granulocytes (about 5800 counts $/ \mathrm{min} \times 10^{3} \times 50000$ cells vs. about 4500 counts $/ \mathrm{min} \times 10^{3} \times 50000$ cells for CL1) during and after apheresis. The respective peak time values, however, increased slightly. The chemiluminescence peak maximum values from unstimulated granulocytes $(\mathrm{C} 1$ and $\mathrm{C} 2)$, i. e. native chemiluminescence, increased.

\section{Discussion}

The question of what causes adverse clinical reactions during centrifugation cytapheresis has been the subject of several previous investigations. These studies investigated the possible role of complement activation (11), lymphocyte and monocyte function (12) and immunological changes (13). The potential role of granulocytes, however, was not taken into consideration.

Several acute and chronic disorders are associated with neutrophil-mediated injury. Upon interaction with a variety of soluble and particulate stimuli, neutrophils can generate large amounts of intermediate products of oxygen reduction (e. g. superoxide anion, hydrogen peroxide, hydroxyl radical) with a concomitant discharge of primary and secondary granule contents (e. g. elastase, cathepsin) (4). Increasing evidence suggests that either one or both of these events are involved in the frequently observed adverse reactions to other models of extracorporeal blood circuits such as dialysis and cardiopulmonary bypass $(5-10)$. In analogy, we have attempted to characterize the functional state of granulocytes from donors undergoing centrifugation cytapheresis.

Noteworthy among the clinical laboratory parameters observed in this study was the increase in plasma complexed elastase. For several reasons, elastase determination in plasma is a sensitive parameter of the functional state of the granulocytes:

(1) the immunological test employed is sensitive for granulocyte-elastase only (22);

(2) in a given volume of whole blood (haematocrit $0.43,3.3 \times 10^{9}$ granulocytes per 1) the intracellular content of elastase $\left(10000 \mu \mathrm{g} / 10^{9}\right.$ granulocytes (26)) is 500 -times higher than that of plasma $(140 \mu \mathrm{g} / 1$ reference value);

(3) the intravascular disappearance rate of complexed elastase is $2.5 \mathrm{~h} \mathrm{(9)}$; the blood collection time intervals of $0.75 \mathrm{~h}$ and $0.5 \mathrm{~h}$ should therefore have been short enough to detect changes. 


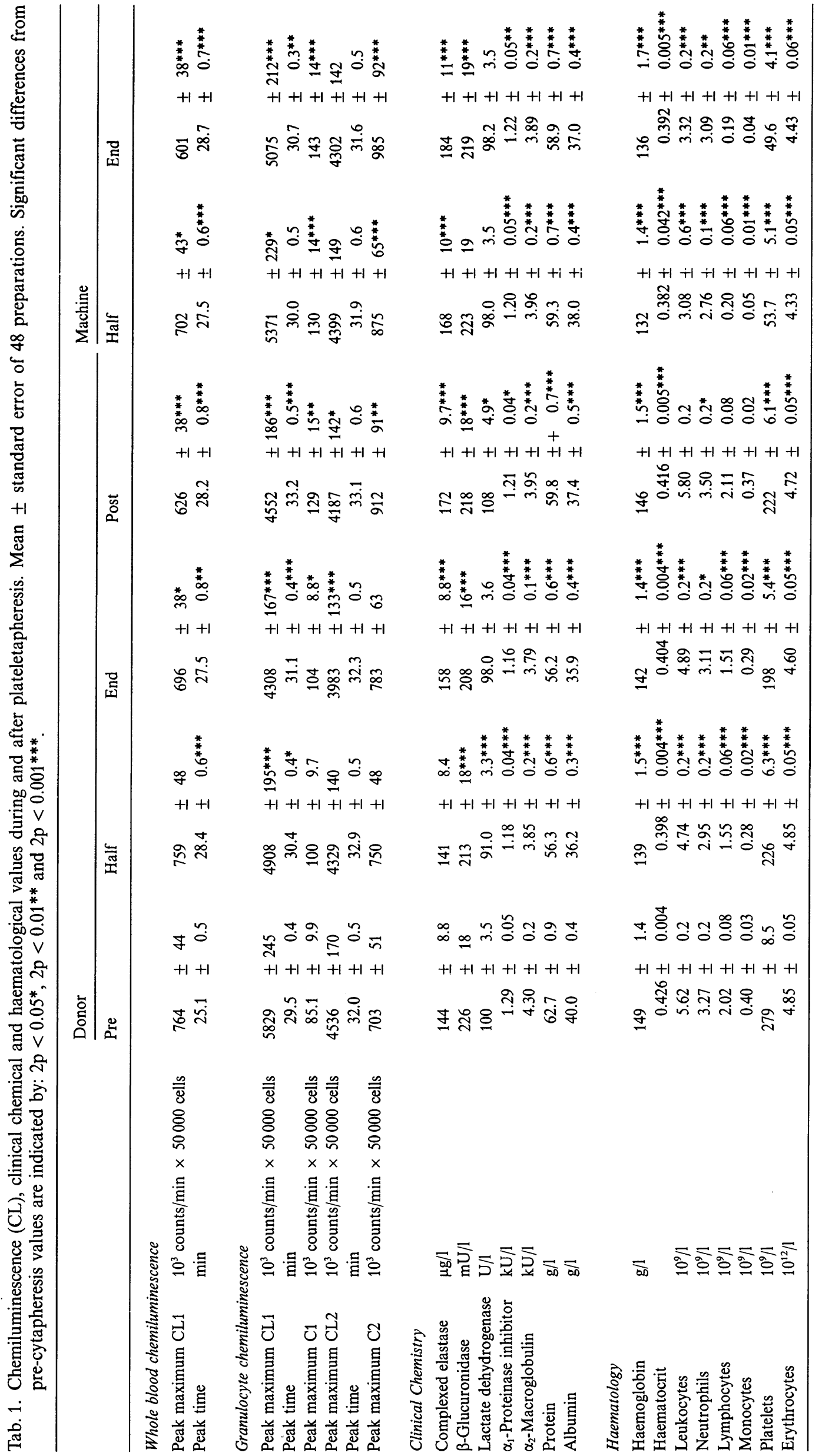


The values from machine efferent fluid were higher than those from the corresponding donor fluid, indicating a more preferential in-vitro release. Although the tendency is definitive, this increase is by no means of clinical importance. In contrast, increases of complexed elastase values during haemodialysis of more than 10-times above normal have been observed, depending on the type of dialysis membrane used (6-9).

Accordingly, granulocyte/plasma ratios of only about 10 for $\beta$-glucuronidase and lactate dehydrogenase (based on normal plasma values of $230 \mathrm{mU} / 1$ and 100 $\mathrm{U} / 1$, respectively, and a granulocyte content of 360 $\mathrm{mU} / 10^{9}$ cells and $140 \mathrm{U} / 10^{9}$ cells, respectively, (26)) cannot mirror the minor release reaction of the granulocytes.

Because of its occurrence in all blood cells $\left(5.8 \mathrm{U} / 10^{9}\right.$ platelets, $142 \mathrm{U} / 10^{9}$ mononuclear cells, $140 \mathrm{U} / 10^{9}$ granulocytes, $4.1 \mathrm{U} / 10^{9}$ erythrocytes) (27)), with a resulting blood cell/plasma ratio of about 360 , lactate dehydrogenase can serve as a general cell injury marker.

$\alpha_{1}$-Proteinase inhibitor and $\alpha_{2}$-macroglobulin are the two major plasma antiproteinases capable of inactivating granulocyte elastase; $\alpha_{1}$-proteinase inhibitor additionally acts as acute-phase protein (28). Considering the results for complexed elastase, it is not surprising that these antiproteinases did not increase. The cytapheresis time may be too short for an acutephase reaction to occur. However, during haemodialysis, slight increases in $\alpha_{1}$-proteinase inhibitor and $\alpha_{2}$-macroglobulin have been observed, although infrequently $(6,7)$.

Since the number of phagocytes was standardized, the observed decreases in the stimulation reactions in

\section{References}

1. Strauss, R. G., Koepke, J. A., Maguire, L. C. \& Thompson, J. S. (1980) Clinical and laboratory effects on donors of intermittent-flow centrifugation platelet-leukapheresis performed with hydroxyethyl starch and citrate. Clin. Lab. Haematol. 2, 1-11.

2. Strauss, R. G., Hester, J. P., Vogler, W. R., Higby, D. J., Snikeris, A. C., Imig, K. M., Graezel, C., Mallard, G., Burnett, D., Gupta, S. \& Hulse, J. D. (1986) A multicenter trial to document the efficacy and safety of a rapidly excreted analog of hydroxyethyl starch with a note on steroid stimulation of granulocyte donors. Transfusion $26,258-$ 264.

3. Strauss, R. G., Goeken, J. A., Eckermann, I., McEntegart, C. M. \& Hulse, J. D. (1986) Effects of intensive granulocyte donation on donors and yields. Transfusion $26,441-445$.

4. Henson, P. M. \& Johnston, Jr., R. B. (1987) Tissue injury in inflammation. Oxydants, proteinases and cationic proteins. J. Clin. Invest. 79, 669-744.

5. Nguyen, A. T., Lethias, C., Zingraff, J., Herbelin, A., Naret, C. \& Descamps-Latscha, B. (1985) Hemodialysis membrane-induced activation of phagocyte oxidative metabolism detected in vivo and in vitro within microamounts of whole blood. Kidney Int. 28, 158-167. whole blood chemiluminescence and isolated granulocyte chemiluminescence are independent of plasma volume expansion. One could, however, argue that the decrease in chemiluminescence is the result of an increased citrate concentration during the apharesis procedure. We have, however, recently shown that increasing the citrated plasma volume fraction while holding erythrocyte and neutrophil numbers constant results in steadily increasing peak maximum values. In addition, a shift to a higher volume fraction of citrated plasma against a lower volume fraction of erythrocytes has been shown to increase peak maximum counts (18). The decrease in opsonin-dependent (CL1), as well as in opsonin-independent (CL2) peak maximum values from isolated granulocytes does not indicate a more preferential plasma- or cell-mediated alteration.

An increased chemiluminescence from isolated cells in the resting state $(\mathrm{C} 1$ and $\mathrm{C} 2)$ was found. This increase suggests that the cytapheresis procedure generates a plasma component capable of stimulating the oxidative metabolism by itself and/or interacting with specific receptors on cell membranes. This saturation and/or deactivation may then result in diminished chemiluminescence upon stimulation. In contrast to filtration cytapheresis, complement activation is unlikely to occur during centrifugation cytapheresis (11). Complement acitvation is characteristically accompanied by increased chemiluminescence activity by stimulated cells $(5,10)$ and clinical symptoms of pulmonary sequestration of leukocytes (9). In conclusion, our results for granulocyte-related cellular and humoral parameters provide no significant evidence of cytapheresis-mediated activation or release reactions of clinical consequence.
6. Hörl, W. H., Schaefer, R. M. \& Heidland, A. (1985) Effect of different dialyzers on proteinases and proteinase inhibitors during hemodialysis. Am. J. Nephrol. 5, 320-326.

7. Hörl, W. H., Steinhauer, H. B. \& Schollmeyer, P. (1985) Plasma levels of granulocyte elastase during hemodialysis. Kidney Int. 28, $791-796$.

8. Knudsen, F., Nielsen, A. H., Pedersen, J. O., Grunnet, N. \& Jersild, C. (1985) Adult respiratory distress-like syndrome during hemodialysis: relationship between activation of complement, leukopenia, and release of granulocyte elastase. Int. J. Artif. Org. 8, 187-194.

9. Knudsen, F., Nielsen, A. H., Pedersen, J. O. \& Jersild, C. (1985) On the kinetics of complement activation, leukopenia and granulocyte-elastase release induced by haemodialysis. Scand. J. Clin. Lab. Invest. 45, 759-766.

10. van Oeveren, W., Kazatchkine, M. D., Deschamps-Latscha, B., Maillet, F., Fischer, E., Carpentier, A. \& Wildevuur, C. R. H. (1985) Deleterious effects of cardiopulmonary bypass. A prospective study of bubble versus membrane oxygenation. J. Thorac. Cardiovasc. Surg. 89, 888-899.

11. Strauss, R. G., Spitzer, R. E., Stitzel, A. E., Urmson, J. R., Maguire, L. C., Koepke, J. A. \& Thompson, J. S. (1980) Complement changes during leukapheresis. Transfusion 20 , $32-38$. 
12. Lopez-Berestein, G., Reuben, J., Hersh, E. M., Kilbourn, R., Hester, J. P., Bielski, M., Talpaz, M. \& Mavlight, G. M. (1983) Comparative functional analysis of lymphocytes and monocytes from plateletapheresis. Transfusion 23, $201-206$.

13. Orsini, F., Fitzpatrick, J., Cohen, E., Khurana, U., Michielson, C., Chadha, K. C., Han, T. \& Ozer, H. (1982) Effects of source leukocyte collection on the immune system. Vox Sang. 43, 11-19.

14. Harvey, C. B. \& O'Rear, E. A. (1986) Velocities and stress levels of axisymmetric, azimuthal flow within the toroidal rotary seal of the IBM 2997 continuous flow cell separator and the implications. J. Biomech. 19, 579-587.

15. Lindena, J., Wittenberg, H., Diederichs, F. \& Trautschold, I. (1986) The decline of catalytic enzyme activity concentration of in vivo ageing erythrocytes of the man, the dog and the rat. J. Clin. Chem. Clin. Biochem. 24, 49-59.

16. Lindena, J. \& Burkhardt, H. (1988) Separation and chemiluminescence properties of human, canine and rat polymorphonuclear cells. J. Immunol. Methods 115, 141-147.

17. Allen, R. C., Mead, M. E. \& Kelly, J. L. (1985) Phagocyte oxygenation activity measured by chemiluminescence and chemiluminescence probing: In: CRC Handbook of methods for oxygen radical research (Greenwald, R. A., ed.). CRC Press, Inc., Boca Raton, pp. 343-351.

18. Lindena, J., Burkhardt, H. \& Dwenger, A. (1987) Mechanisms of non-opsonized zymosan-induced and luminol-enhanced chemiluminescence in whole blood and isolated phagocytes. J. Clin. Chem. Clin. Biochem. 25, 765-778.

19. The commissions for enzyme diagnostics and standardisation. Recommendations of the German Society for Clinical Chemistry. Standardisation of methods for the estimation of enzyme activities in biological fluids. Z. Klin. Chem. Klin. Biochem. 10, 281-291.
20. Witt, I. \& Tritschler, W. (1982) $\alpha_{1}$-Antitrypsin: Referenzwerte in Serum und Plasma mit Benzoyl-D,L-arginin-pnitroanilid, einem chromogenen Substrat. J. Clin. Chem. Clin. Biochem. 20, 587-591.

21. Witt, I. \& Tritschler, W. (1983) $\alpha_{2}$-Makroglobulin in Serum und Plasma: Referenzwerte mit Carbobenzoxy-valyl-glycylarginin-p-nitroanilid, einem chromogenen Substrat. J. Clin. Chem. Clin. Biochem. 21, 429-436.

22. Neumann, S., Gunzer, G., Hennrich, N. \& Lang, H. (1984) "PMN-elastase-assay": enzyme immunoassay for human polymorphonuclear elastase complexed with alpha-1-proteinase inhibitor. J. Clin. Chem. Clin. Biochem. 22, 693697.

23. Yatziv, S., Kahane, I., Abeliuk, P., Cividalli, G. \& Rachmilewitz, E. A. (1979) "Lysosomal" enzyme activities in red blood cells of normal individuals and patients with homozygous beta-thalassaemia. Clin. Chim. Acta 96, 67-72.

24. Schirardin, H. \& Ney, J. (1972) Eine vereinfachte Mikromethode zur Bestimmung von Serumalbumin mit Hilfe von Bromkresolgrün. Z. Klin. Chem. Klin. Biochem. 10, $338-$ 344.

25. Kalmin, N. D. \& Grindon, A. J. (1983) Comparison of two continuous-flow separators. Transfusion 23, 197-200.

26. Dwenger, A., Schweitzer, G. \& Regel, G. (1986) Bronchoalveolar lavage fluid and plasma proteins, chemiluminescence response and protein contents of polymorphonuclear leukocytes from blood and lavage fluid in traumatized patients. J. Clin. Chem. Clin. Biochem. 24, 73-88.

27. Lindena, J., Sommerfeld, U., Hoepfel, C., Wolkersdorfer, R. \& Trautschold, I. (1983) Enzyme activities in blood cells of man and dogs after separation on a discontinuous Percoll gradient. Enzyme 29, 100-108.

28. Jochum, M., Duswald, K. H., Neumann, S., Witte, J. \& Fritz, H. (1984) Proteinases and their inhibitors in septicemia - basis concepts and clincial implications. Adv. Exp. Med. Biol. 167, $391-340$.

Joachim Lindena, DVM

Abteilung Klinische Biochemie

Medizinische Hochschule Hannover

Konstanty-Gutschow-Straße 8

D-3000 Hannover 61 